\title{
Progress and Prospects Research in Marketing Communication: Chinese and Western Approaches
}

\begin{abstract}
Danko Yuriy a, Wu Ling Ling ${ }^{\text {b }}$, Doctor of economics, professor, ViceRector for Scientific Work, Sumy National Agrarian University, Sumy, Ukraine, beputy Director of Propaganda Department, Henan Institute of Science and Technology, Henan, China, Ph.D student of Economics and Management Department, Sumy National Agrarian University, Sumy, Ukraine Email: ${ }^{a}$ y.danko@ snau.edu.ua, b28995695@qq.com
\end{abstract}

\begin{abstract}
This paper collects and analyses the journal articles and masters theses published in English and Chinese on marketing communication research in the past 20 years. The research aims to sort out and summarise the research results of marketing communication in Chinese and foreign universities, and grasp the research situation of marketing communication in Chinese universities as a whole. The research aims to provide technical support for the construction of an effective marketing communication system for Chinese universities and subsequent research. At present no scholars have especially researched, defined and summarised the construction of the university marketing communication system.
\end{abstract}

Key words: Marketing communication, universities, China, marketing, education.

\section{Introduction}

At present, most Chinese universities have realised that the changes in the external environment have brought great impacts on the development of schools, and they have felt competitive pressures from various aspects, for example, in particular social resources, highquality students, graduate employment, excellent teachers, social relations, fundraising, school image shaping. In the fierce market competition environment, in order to survive and develop, we believe that all levels of universities must change their concepts to introduce marketing communication concepts into the operation of universities, and establish effective marketing mechanisms to adapt to market changes. Maximising the function of marketing communication, effectively promotes itself in a competitive atmosphere, and promotes the formation of a good social image, as well as enhances the overall competitive strength. It maximises the beneficial resources, and fundamentally improves the educational resources of 
International Journal of Innovation, Creativity and Change. www.ijicc.net

Volume 13, Issue 7, 2020

universities, effectively achieving the goals of running a school, promoting the rapid development of universities, and better fulfilling the mission entrusted by society.

\section{Research Methodology}

This study was mainly carried out by literature review. Through summarising the related research on marketing communication in colleges and universities, this paper aims to sort out and summarise the research results of marketing communication in Chinese and foreign universities, grasping the research situation of marketing communication in Chinese universities as a whole, and clarifying the value and necessity of marketing communication in Chinese universities. Effective Chinese university marketing communication system model provides technical support. In order to ensure the comprehensiveness of the literature collection, we have selected journal articles and masters theses published in English and Chinese over the past 20 years. Search for the original literature through Scopus, Web of Science, Google Scholar, and CNKI search engines. Through the "marketing communication", "colleges", "university" and other keywords to search for too few documents, we have expanded the keyword to "university", "school", "college", "marketing", "education marketing" and so on. In Scopus, a total of nine related articles were found. In CNKI, a total of 28 related articles were found. In Google Scholar, a total of 1030 related articles were found. In addition, some papers and monographs have been found in the references to selected articles. We excluded research papers that were not related to university marketing communication and system construction, and carefully examined the relevance of these articles to this study. Based on the criteria of the relevance of the topic, and the number of citations for exclusion, there were 53 items from the literature that were finally screened for comparative analysis.

\section{Literature Review}

\section{Research Progress in Marketing Communication in Universities}

We first analysed the articles most closely related to this study, namely the articles searched for by keywords such as "marketing communications", "university", "school" and "college", and analysed them.

Rutter, Lettice and Nadeau (2017) describe the university prospectus as an important marketing communication tool for higher education enrollment strategies. However, many researchers focus on other media such as social media and websites, brought it to be ignored. The article explores and analyses the development prospects of the top ten universities in the UK, and compares the relative position of their brand personality in marketing communication to the perspective of brand personality. Malačka (2015) conducted a 
International Journal of Innovation, Creativity and Change. www.ijicc.net Volume 13, Issue 7, 2020

preliminary study on the selection of potential research applicants. The article explores the identification of the main factors that influence the decision-making of potential research applicants when choosing a university and the sources of information needed for decisionmaking. Vaštíková, Matušínská and Vaněk (2011) evaluated the applicability of individual communication tools in college marketing communication strategies; and described communication strategies, monitoring effects and research results. They proposed new trends in marketing communication strategies. Boffo (2004)investigated and analysed the activities of Italian universities and colleges. The results showed that the Italian higher education institutions have formed a large-scale public relations, communication, and marketing activities. However, the survey emphasises that activities are mostly limited to the organisation of the activity, and the "metabolism" of the competitive function of communication is quite long and may be quite difficult.

In the articles obtained after searching for the keyword "marketing communications" "college", there are two related researches. Slabá, Martíšková and Švec (2018) analyse the college students in the Czech higher education market, identify key stakeholder groups in marketing communication in colleges and universities, and summarise the results of pilot studies of some public and private universities in the Czech Republic. Researchers demonstrated the possibility of using the stakeholder approach to identify and prioritise key stakeholder groups in college marketing communications. The article emphasised that in the context of the changing situation of the higher education market in the Czech Republic and the Slovak Republic. It is necessary to use market propaganda, introduce the basic steps and research methods of stakeholder research, and finally determine the most important interests in the marketing communication of colleges and universities, including specific departments, faculty, media, potential and students, marketing and public relations departments. The research results show that the importance of internal communication must be supported by marketing communication in universities, followed by media relations to improve the positive image and good reputation of colleges and universities.

Through the CNKI academic journals and ProQuest Dissertations \& Theses Database, the author accurately searched all the Chinese documents that are included. After carefully examining the relevance of the literature to the study, we found that only four of the 45 articles were relevant to the study. Yang Li (2015) analysed the status of enrollment publicity in open universities and applied the integrated marketing communication theory to the open enrollment work of open universities. He tried to build a new open enrollment propaganda strategy framework in university. The framework is centered on integration, based on big data, refined classification, and flexible use of current propaganda methods.

One more the article analyses the importance of building a university brand by drawing on the concept of integrated marketing communication. The article puts forward the process of 
International Journal of Innovation, Creativity and Change. www.ijicc.net

Volume 13, Issue 7, 2020

integrating marketing communication thinking and constructing an effective university brand communication process (Lin, 2009).

In the own article Li Qiu and Wang Liqin ( $\mathrm{Li}$ 2005) discussed the impact of integrated marketing communication theory on private education advertising in today's education industrialisation. The article defines the role of advertising in entering the integrated marketing stage, and the influence and role of advertising effects in the construction of private education brands.

From this, we can see that there is very little research on marketing communication in universities, both in China and internationally. On this basis, we have also carried out a comprehensive analysis of other papers collected, and organised and described them in two parts - domestic and foreign. At the same time, each part is sorted out according to the development of marketing communication and marketing communication in the field of education, that is, each part is divided into two main lines: Research progress of marketing communication, and research progress of higher education marketing.

\section{Marketing Communication Progress}

We presented the studies of European and American scholars in the form of Table 1. Our studies have shown that the process of establishing these terms has come a long way, since the emergence of a marketing system in these countries occurred earlier than in China. There is a lot of explanation for this fact, but the main thing is the closeness of economic systems and the distinction of the "planned" and market economies. 
International Journal of Innovation, Creativity and Change. www.ijicc.net Volume 13, Issue 7, 2020

Table 1: Foreign marketing communication research progress

\begin{tabular}{|c|c|}
\hline Representative & View \\
\hline (Bowden, 1950) & $\begin{array}{l}\text { Propose a "marketing mix" and identify } 12 \text { elements of the } \\
\text { marketing mix }\end{array}$ \\
\hline (Mc Ginwick, 1957) & $\begin{array}{l}\text { Put forward the "marketing concept" theory, claiming that it is the } \\
\text { key to business efficiency and long-term profitability }\end{array}$ \\
\hline (McCarthy, 1960) & $\begin{array}{l}\text { Propose "4Ps" theory, namely Product, Price, Place/Distribution, } \\
\text { and Promotion }\end{array}$ \\
\hline (Crane, 1965) & $\begin{array}{l}\text { Marketing communication is a kind of behavioral view about } \\
\text { people, information and media }\end{array}$ \\
\hline (Duncan, 1993) & $\begin{array}{l}\text { Reviewing and combing the changes in the field of marketing } \\
\text { communication in the United States, and discovering that there is } \\
\text { no authoritative definition of integrated marketing communication. }\end{array}$ \\
\hline (Schultz, 2003) & $\begin{array}{l}\text { The integrated marketing communication process is divided into } \\
\text { five steps: one is to identify customers and potential customers; the } \\
\text { other is to evaluate the value of customers and potential customers; } \\
\text { the third is planning information and incentives; the fourth is to } \\
\text { evaluate the return on investment of customers; the fifth is the } \\
\text { analysis after project execution and future plan }\end{array}$ \\
\hline (Simp, 2005) & $\begin{array}{l}\text { From the aspects of advertising management, promotion } \\
\text { management, market-oriented public relations and sponsorship } \\
\text { marketing, the specific operation of integrated marketing } \\
\text { communication is discussed. }\end{array}$ \\
\hline (Bruen, 2005) & $\begin{array}{l}\text { Promote the concept of integration to a strategic and artistic policy } \\
\text { level, focusing on the comprehensive research of integrated } \\
\text { marketing communication from different levels of corporate } \\
\text { communication. }\end{array}$ \\
\hline (Peckton, 2011) & $\begin{array}{l}\text { Three models of integrated marketing communication are } \\
\text { discussed: the process model of integrated marketing } \\
\text { communication, the RABOSTIC planning model of integrated } \\
\text { marketing communication, and the integrated marketing } \\
\text { communication combination model. }\end{array}$ \\
\hline
\end{tabular}

In Chinese scientific literature, the concept of marketing communications appears much later. It matured in the 1980s and was introduced to China (Zhu Lin, 2015). However, it should be made clear that domestic research on marketing communication and related theories does not begin with the "marketing communication" theory, but crosses this stage and begins directly with the introduction of the "integrated marketing communication theory" (Xing Lliang, 2013). 
International Journal of Innovation, Creativity and Change. www.ijicc.net

Volume 13, Issue 7, 2020

It is generally believed, that the earliest systematic introduction to the theory of integrated marketing communication in China is a series of seven articles published by Lu Taihong and others in International Advertising magazine. In May 2001, Professor Shen Guanglong of Nankai University put forward the idea of strategic management of enterprise integrated marketing communication (Shen Guanglong, 2001). In 2005, Wei Junying, combed the development of marketing communication theory and the inevitability of the emergence of integrated marketing communication. On this basis, the workflow, target strategy and tactical operation of integrated marketing communications were comprehensively discussed (Wei Junying, 2005). In 2007, Wen Shuo, combined with the marketing experience of the company published "Integrated Marketing Communication" centered on the 4C theory, proposing "the idea of using integrated marketing to disseminate armed domestic products". He pointed out the company's integrated marketing communication strategy from four aspects: Integrated marketing communication planning, creativity and execution, behaviour and testing, measurement affairs and operational skills (Wen Shuo, 2007). In 2008, Zou Ruitao conducted a thorough study on the related concepts of integrated marketing communication strategy. In the process of introducing marketing related theories, he analysed the IMC related theories of domestic and foreign scholars. Based on the perspective of organisational practice, he analyses the key factors needed for business success and comprehensively explores the prospects of developing integrated marketing communication strategies in China (Zou Ruitao, 2008).

Researcher Xing Liang (2013) believes that in the development of marketing communication theory its main evolutionary trajectory is evolutionary path of the four theories: "Marketing communication" theory (MC), "integrated marketing communication" theory (IMC), brand marketing communication theory (BMC), and digital marketing communication theory (DMC).In the process of evolution, the degree of integration of the entire social marketing system is getting higher and higher.

In recent years, with the continuous popularisation and practice of integrated marketing communication theory in China, more and more scholars have studied integrated marketing communication, mainly focusing on integrating marketing communication theory research and integrating marketing communication. 
International Journal of Innovation, Creativity and Change. www.ijicc.net Volume 13, Issue 7, 2020

Table 2: List of China's domestic marketing communication research progress

\begin{tabular}{|l|l|}
\hline Representative & View \\
Magazine, 1994 & Discussed IMC \\
\hline Lu Hongtai, 1996 & $\begin{array}{l}\text { System Introduction Integrated Marketing Communication } \\
\text { Theory }\end{array}$ \\
\hline Shen Guanglong, 2001 & $\begin{array}{l}\text { Put forward the idea of enterprise integrated marketing } \\
\text { communication strategy management }\end{array}$ \\
\hline Wei Junying, 2005 & $\begin{array}{l}\text { A comprehensive discussion of the workflow, target strategy } \\
\text { and tactical operation of integrated marketing communication }\end{array}$ \\
\hline Wen Shuo, 2007 & $\begin{array}{l}\text { Put forward the idea of "distributing armed domestic products } \\
\text { with integrated marketing", and point out the integrated } \\
\text { marketing communication strategy of enterprises from four } \\
\text { aspects: integrated marketing communication planning, } \\
\text { creativity and execution, behavior and testing, measurement } \\
\text { affairs and operational skills. }\end{array}$ \\
\hline Zou Ruitao, 2008 & $\begin{array}{l}\text { The paper thoroughly studies the related concepts of integrated } \\
\text { marketing communication strategies, analyses the relevant } \\
\text { IMC related theories by domestic and foreign scholars, and } \\
\text { comprehensively explores the prospects of developing } \\
\text { integrated marketing communication strategies in China. }\end{array}$ \\
\hline Xing Liang, 2013 & $\begin{array}{l}\text { The system sorts out the evolutionary development path of } \\
\text { marketing communication theory }\end{array}$ \\
\hline
\end{tabular}

\section{Progress in China's Domestic Higher Education Marketing Research}

After China's accession to the WTO, with the opening up of the education market, the challenges faced by foreign higher education organisations are placed in front of China's higher education managers and policy makers. The study of industrialisation and marketisation of higher education is also increasing among Chinese scholars. Some scholars realise that since the operation of higher education has market attributes or partial market attributes, marketing strategies, ideas or models are one of the things that higher education organisations deserve to learn from enterprises (Lan Wenqiao, 2007).

It's proposed that the marketing strategy of higher education is to use the marketing concept to manage higher education. More attention should be paid to educating consumers about the needs of consumers, not just the needs of higher education organisers and managers. Higher education institutions should consider all aspects related to educating consumers, parents, and social groups to meet their needs, such as quality education, organisational management, and logistics support (Hui Xi, 2002). 
International Journal of Innovation, Creativity and Change. www.ijicc.net

Volume 13, Issue 7, 2020

Reseacher Pan Shaolai (2008) pointed out that education marketing is a market management process. In this process, educational institutions at all levels achieve educational goals by creating educational services that meet social and individual needs while maintaining the survival and development of educational institutions (Pan Shaolai, 2008).

It's believed that universities are faced with good opportunities to use the market mechanism to achieve their own development, but also face increasingly fierce competition. Therefore, it is possible and inevitable to introduce marketing concepts into university operations. Universities must respect the inherent laws of education and establish a school-running philosophy oriented to the needs of social development. At the same time, universities should choose their service targets based on their own resource conditions and school traditions. The university should also pay attention to long-term development and make overall arrangements for resource allocation, teaching and research, and management activities. Therefore, university marketing has become an inevitable choice to adapt to the market economy environment (Du Xiangmin, 2009).

Chinese universities are faced with the opportunity to use the market mechanism to achieve self-development and face fierce competition at home and abroad. It is possible and inevitable for universities to implement brand management. The university should strengthen the brand management concept, clarify the brand positioning, build a strong brand, promote the dominant brand, and establish a brand crisis management system. Through brand management, strengthen the university's core competitiveness to obtain greater benefits (Wang Jingrong, Bai Yang, 2009).

In the process of the development of university education in our country, the best cultivation of university brands has become a problem that must be solved in order to promote the further development of higher education. He explored how to be market-oriented, and introduce advanced marketing concepts to cultivate and build university brands, thereby improving the school's ability to run schools and competitiveness (Li Jintao, 2012).

\section{Conclusion}

After sorting out all the literature and synthesising the vast majority of relevant research, we have the following results:

1. At present, there are few studies on marketing communication in colleges and universities at home and abroad. Although people have recognised the importance of marketing communication to enhance the visibility of colleges and universities and strengthen the brand building of colleges and universities, the degree of awareness and emphasis on strengthening marketing communication in colleges and universities is still lacking. At present, the 
combination of college propaganda work and marketing communication theory is seriously inadequate. At present, there is no scholarly special research, definition, and summary of the construction of a university marketing communication system.

2. The research results of higher education marketing show that China's colleges and universities are indeed facing fierce domestic and international competition. Under the background of higher education marketisation, it is imperative to use the market mechanism to seize the opportunity for colleges to achieve self-development and introduce advanced marketing concepts to promote the university's overall ability and competitiveness.

3 . The research results of integrated marketing show that the concept of integrated marketing communication is considered to be the most important development of marketing in the 1990s. Integrated marketing communication integrates marketing and communication into the process of communication and practice in China. It provides a marketing communication framework model for enterprises and provides many effective practical cases. Integrated marketing communication has become an important theoretical and practical guiding tool for Chinese enterprises to effectively attract consumers and strive for maximum profit for enterprises in the face of market competition. These experiences have certain significance for other industries. 
International Journal of Innovation, Creativity and Change. www.ijicc.net

Volume 13, Issue 7, 2020

\section{REFERENCES}

Boffo, S. (2004). Universities and marketing mass communication in Italy. Higher Education Policy, 17(4), 371-381.

Broderick, A., \& Pickton, D. (2005). Integrated marketing communications. Pearson Education UK.

Du Xiangmin, Wang Jiankang. (2009) Application Research of Marketing Concept in University Management. Science and Technology Society, 27(2), 118-120

Duncan, T. R., \& Everett, S. E. (1993). Client perceptions of integrated marketing communications. Journal of advertising research, 33(3), 30-40.

Hui Xi. (2002) A Probe into the Marketing Strategy of Higher Education. Liaoning Education Research. (9)

Ganushchak-Efimenko, L., Shcherbak, V., Nifatova, O., Kolodiziev, O., \& Rębilas, R. (2019). Methodological framework for integrated business structures branding development in ukraine. Innovative Marketing, 15(2), 14-29

Lan Wenqiao (2006) Burton Clarke's Interpretation of the Integration of Higher Education System - Also on the Conflict and Adjustment of the Relationship between University, Government and Market. Journal of Liaoning Normal University. (1)

Lan Wenqiao (2007) Research on Higher Education Products and Marketing. [Master's thesis]: Shenyang Normal University,

Li Jintao (2012) On the Enlightenment of Marketing Concept to the Development of University Brands. China Business, 2012, (33): 40-41.

Li Qiu, Wang Liqin.The (2005) Application of Integrated Marketing Communication in the Construction of Private Education Brands. Teaching Research, (02):135-136

Lin Minfang (2009) College Brand Construction under the Thought of Integrated Marketing Communication. Jiangxi Education, (Z1):53-55.

Malačka, L. (2015) Role of marketing communication in applicants' choice of university. Acta Universitatis Agriculturae et Silviculturae Mendelianae Brunensis 63(4), 13111322 
International Journal of Innovation, Creativity and Change. www.ijicc.net Volume 13, Issue 7, 2020

Markina, I., Zhuravska, N., Yashchuk, S., Opaliuk, T., \& Karapuzova, N. (2020). The formation of the adaptive model of educational management in the sphere of higher education. International Journal of Innovation, Creativity and Change, 11(5), 200-217.

Pan Shaolai (2008) Analysis and Re-recognition of Educational Marketing Concepts. Liaoning Education Research, (2):46-49.

Rutter, R., Lettice, F., \& Nadeau, J. (2017). Brand personality in higher education: anthropomorphized university marketing communications. Journal of Marketing for Higher Education, 27(1), 19-39.

Schultz D. E., Kitchen P. J. (2000) Communicating Globally: An Integrated Marketing Approach, Publisher: McGraw-Hill; 72, 1st edition, ISBN-10: 0844225223

Schultz, D. E. (1992). Integrated marketing communications. Journal of Promotion Management, 1(1), 99-104.

Shen Guanglong (2001) Integrated Marketing Communication Strategy Management. China Materials Publishing House,

Slabá, M., Martíšková, P., \& Švec, R. (2018). Usage of urgency variable in marketing communication of colleges. Paper presented at the Proceedings of the 31st International Business Information Management Association Conference, IBIMA 2018: Innovation Management and Education Excellence through Vision 2020, 4804-4810

Terence A.. Shimp. (2003). Advertising, Promotion \& Supplemental Aspects of Integrated Marketing Communications. Thomson South-Western..

Vastikova, M., Matusinska, K., \& Vanek, J. (2011). The aspects of marketing communication of universities with respect to winning new customers/Aspekty marketingove komunikace vysoke skoly vzhledem k ziskani novych zakazniku. E+ M Ekonomie a Management, (3), 100.

Wang Jingrong, Bai Yang. (2009) Application of Brand Marketing Strategy in University Brand Management[J]. Social Scientist, (8): 115-117, 123.

Wei Junying (2005) Integrated Marketing Communication: Concepts and Methods. Hangzhou: Zhejiang University Press,: 2.

Wen Shuo et al., (2007) Integrated Marketing Communication. Business Press,

Xing Liang (2013) Research on the Evolution of Marketing Communication Theory. [PhD thesis]: Jinan University,. 
International Journal of Innovation, Creativity and Change. www.ijicc.net Volume 13, Issue 7, 2020

Yang Li.The (2015) Application of Integrated Marketing Communication Theory in Enrollment of Open University. Journal of Tianjin Radio and TV University, 19(02):2023.

Zhu Lin, Li Huashu, Luo Jiacai.Marketing (2015) Management of Provincial High-level University Transformation and Development. Journal of Sichuan University of Science and Technology (Social Science Edition), 30(1): 22-33.

Zou Ruitao (2008) Integrated Marketing Communication Strategy and Organizational Practice. [Master's thesis]: Wuhan University of Science and Technology. 